\title{
KEHIDUPAN SOSIAL BUDAYA MASYARAKAT ISLAM DI DESA RASABOU KECAMATAN SAPE KABUPATEN BIMA (1931-1997)
}

\author{
Dian Marhaeni Widyastuti \\ Pendidikan Sejarah, SMK N 1 Sape, Dianwidyastuti@gmail.com
}

\begin{tabular}{l} 
INFO ARTIKEL \\
RiwayatArtikel: \\
Diterima:07-04-2017 \\
Disetujui:06-05-2017 \\
\hline
\end{tabular}

Kata Kunci:

1. Kehidupan Sosial Budaya

2. Masyarakat Islam

\begin{abstract}
ABSTRAK
Penelitian ini bertujuan untuk mengetahui Kehidupan Sosial Budaya Masyarakat Islam, khususnya sejarah masuknya Islam, kondisi Kehidupan Sosial Budaya dan faktor-faktor penghambat dan pendukung pengembangan Islam di Sape Rasabou Kabupaten Bima. Penelitian ini mengunakan metode Historis yaitu melalui tahap Heuristik, Kritik, Interpretasi dan Histografi. Analisis data yang digunakan adalah Historis analisis, dan metode kualitatif. Hasil penelitian menunjukkan, Kondisi kehidupan Sosial Budaya Masyarakat Islam berlangsung dalam kehidupan kegotongroyongan, meskipun terdapat perbedaan status Sosial, namun mulai terjadi pergeseran semenjak masuknya ajaran Islam bahwa manusia sama derajatnya kecuali yang membedakan adalah ketakwaannya. Kehidupan Budaya Masyarakat Islam di Sape Rasabou berkembang sebagaimana perkembangan agama Islam di wilayah tersebut. Kebudayaan islam terbentuk seiring dengan berkembangnya agama Islam.

This study aims to find out the Social and Cultural Life of Islamic Communities, especially the history of the entry of Islam, the condition of Social and Cultural Life and the factors inhibiting and supporting the development of Islam in Sape Rasabou Kabupaten Bima. This research uses Historical method that is through Heuristic, Criticism, Interpretation and Histography. Data analysis used is Historical analysis, and qualitative method. The result of the research shows that the condition of the social life of the Muslim society takes place in the life of mutual cooperation, although there are differences in social status, but there is a shift since the entry of Islamic teachings that human beings are equal except the difference is their piety. The Cultural Life of the Islamic Society in Sape Rasabou developed as the development of Islam in the region. Islamic culture is formed along with the development of Islam.
\end{abstract}

\section{A. LATAR BELAKANG}

Kehidupan Sosial adalah suatu kebersamaan dalam Masyarakat, secara harfiah bermakna kehidupan berasal dari kata hidup artinya masih terus ada bergerak dan bekerja sebagaimana semestinya" (Porwadarminta 1976:36).

Semenjak manusia hidup secara Sosial, tumbuhlah sebuah soal yang harus dipecahkan secara bersama-sama, tidak mungkin kebutuhan seorang dapat terpenuhi sendiri. Sebab itu, semakin kompleks hubungan Sosial, maka bertambah kuat pula ketergantungan satu sama lain untuk memenuhi kebutuhannya.

Sape Rasabou Kabupaten Bima merupakan salah satu Daerah yang mempunyai kehidupan Sosial Budaya yang unik. Tampak pada kehidupan masyarakat yang masih tabu dengan pantangan-pantangan yang berlaku dalam Masyarakat yang disebut dengan "Pamali" atau bahasa Bimanya Tipehe, hal ini berlaku sejak leluhur, kemudian diwariskan pada anak cucunya secara turuntemurun.

Budaya atau kebudayaan berasal dari bahasa Sanskerta yaitu buddhayah, yang merupakan bentuk jamak dari buddhi (budi atau akal) diartikan sebagai hal-hal yang berkaitan dengan budi dan akal manusia. Dalam bahasa Inggris, kebudayaan disebut culture, yang berasal dari kata Latin Colere, yaitu mengolah atau mengerakan. Bisa diartikan juga sebagai mengolah tanah atau bertani. Kata culture juga kadang diterjemahkan sebagai "kultur" dalam bahasa Indonesia.

Menurut Edward Burnett Tylor, Kebudayaan merupakan keseluruhan yang kompleks, yang di dalamnya terkandung pengetahuan, kepercayaan, kesenian, moral, hukum, adat istiadat, dan kemampuan-kemampuan lain yang didapat seseorang sebagai anggota masyarakat.

Jadi definisi Budaya adalah suatu cara hidup yang berkembang dan dimiliki bersama oleh sebuah kelompok 
orang dan diwariskan dari generasi ke generasi. Budaya terbentuk dari banyak unsur yang rumit, termasuk sistem agama dan politik, adat istiadat, bahasa, perkakas, pakaian, bangunan, dan karya seni. Bahasa, sebagaimana juga budaya, merupakan bagian tak terpisahkan dari diri manusia sehingga banyak orang cenderung menganggapnya diwariskan secara genetis. Ketika seseorang berusaha berkomunikasi dengan orang-orang yang berbeda budaya dan menyesuaikan perbedaanperbedaannya.

Islam adalah Agama yang diturunkan Allah kepada Nabi Muhammad SAW, yang mengatur hubungan manusia dengan Khaliq-nya, dengan dirinya dan dengan manusia dengan sesamanya. Hubungan manusia dengan Khaliq-nya tercakup dalam perkara Akidah dan Ibadah. Hubungan Manusia dengan dirinya tercakup dalam perkara Ahlak, makanan dan pakaian. Hubungan manusia dengan sesamanya tercakup dalam perkara Muamalah dan Uqubat (sanksi).

Dengan demikian Islam merupakan prinsip idiologis yang mengatur seluruh aspek kehidupan Islam bukan di Sape Rasabou saja tapi semua Islam yang ada didunia, Aspek islam juga bukan berupa teologi.

Bahkan tidak ada sedikitpun dengan sistem kepastoran. Islam menjauhkan otokrasi/Teokrasi (kedikatoran pemerintahan Agama). Didalam Islam tidak ada istilah (seklompok) ahli agama, juga tidak dijumpai istilah Ahli politik. Setiap orang yang memeluk agama Islam disebut sebagai kaum Muslimin. Semuanya sama dihadapan agama. Jadi didalam islam tidak ada istilah rohanian ataupun teknokrat.

Islam masuk di Sape Kabupaten Bima oleh Kerajaan Gowa Tallo pada Tahun 1609 M. Sejak masuknya Islam di Sape Rasabou Kabupaten Bima yang pertama di daerah bagian timur kemudian menyusul dibagian tengah,barat, dan utara. di Kabupaten Bima, Islam dengan cepat dapat berkembang karena penerimaan Islam berlangsung secara damai oleh masyarakat. Penyebaran Agama Islam di Sape Rasabou kabupaten Bima tidaklah ditempuh dengan bujukan atau pakasaan untuk menganutnya, akan tetapi dilakukan secara damai, tidak ada paksaan sebab Islam adalah agama yang cinta damai dan tidak mengenal paksaan.

\section{B. METODE PENELITIAN}

Penelitian tentang kehidupan sosial budaya masyarakat islam di Sape Rasabou Kabupaten Bima merupakan sebuah kajian budaya (cultural studies) yang menggunakan penelitian kualitatif dengan pendekatan deskriptif-analitis. Teknik Pengumpulan data mengunakan tehnik wawancara (interview), observasi, dokumentasi triangulasi, angket.

\section{HASIL DAN PEMBAHASAN}

Hasil penelitian tentang Kehidupan sosial budaya masyarakat islam di Sape Rasabou kabupaten Bima 19311997 banyak permasalahan yang dihadapi oleh masyarakat, terutama dalam pelaksanaan ajaran Islam,kondisi kehidupan Sosial Budaya masyarakat Islam serta factor-faktor yang menjadi pendukung dan penghambat dalam meningkatkan kehidupan social Budaya Masyarakat Islam di Sape Rasabou Kabupaten Bima yaitu :

\section{Sejarah Masuknya Islam di Sape Rasabou Kabupaten Bima}

Islam Masuknya di Kabupaten Bima melalui kerajaan Gowa-Tallo pada tahun 1609 M. Kedatangan pedagang tersebut ke Bima, bukan hanya semata-mata sebagai pedagang tetapi sambil menyebarkan agama islam. Daerah yang pertama kali didatangi oleh para pedagang islam ialah daerah bagian timur yaitu Daerah Sape, Daerah tersebut dapat menerima ajaran Islam dan mulai menyebar luas ke bagian lainnya pada akhir abad ke-14. (Dra. Hj. Mariam (1971:49).

Dari catatan BO Sangaji kai diketahui peristiwa yang terjadi sekitar waktu menjelang kedatangan para mubaliq islam di Bima, yakni tahun 1018 H. catatan ini memberikan penegasan momentum awal masuknya islam di Makassar. Hal ini disebabkan Sejarah Bima tidak bisa dipisahkan dengan sejarah Makassar karena pada zaman itu Makassar mempunyai pengaruh besar terhadap wilayah-wilayah kerajaan sekitarnya. Termasuk pulau Sumbawa.

Pada abad ke-16 M, Bima sudah menjadi salah satu pusat perdagangan yang ramai di wilayah bagian timur Nusantara. Menurut Tome Pires yang berkunjung ke Bima pada tahun 1513 M, pada masa itu pelabuhan Bima 
ramai dikunjungi oleh para pedagang Nusantara dan para pedagang Bima berlayar menjual barang dagangannya ke Ternate, Banda dan Malaka serta singgah di setiap pelabuhan di Nusantara.

Keterangan Tome Pires diperkuat Panambo Lombok, DR. E Urtrech, SH mengatakan bahwa pengislaman di pulau Bima terjadi pada masa pemerintahan Gowa tallo. dalam keterangan Panambo tersebut sangatlah tepat, karena proses islamisasi di tanah air secara umum tidak dilakukan dengan jalan kekerasan melainkan dengan misi damai, dakwah dan perdagangan serta perkawinan silang.

Berdasarkan kajian dan penelitian itulah, ditetapkan dua tahap masuknya islam di tanah Bima. Hal itu didasarkan pada keterangan dari catatan lokal keterangan kitab BO (kitab sejarah bima, 1951:57), ternyata peranan kerajaan Gowa Tallo sangat besar. Selain itu para pedagang Bima pun memiliki andil dalam penyiaran Islam tahap awal. Secara kronologis pada abad ke-16 M, Bima sudah menjadi salah satu pusat perdagangan yang ramai di wilayah bagian timur Nusantara.

Islam masuk di Bima awalnya hanya bagian timur, lama kelamaan menyebar keseluruh wilayah Bima termasuk Sape Rasabou dan sebagainya, penyebaran agama islam di daerah tersebut berlangsung cukup cepat sebab agama islam tidak pernah membedakan antara kaum bangsawan dengan masyarakat biasa, Siti Maryam, (1965:40).

Jadi, masuknya islam di kabupaten Bima tentunya membawa perubahan mendasar dalam kehidupan sosial budaya masyarakatnya, yang dulunya masih menganut kepercayaan beralih kepada agama islam. Dinamika masyarakat tersebut terjadi baik dari aspek sosial maupun budaya.

2. Kondisi kehidupan social Budaya masyarakat Islam di Sape Rasabou

\section{a. Kondisi social masyarakat Sape Rasabou}

Kondisi sosial sejak awal perkembangan islam di Sape Rasabou telah membawa perubahan mulai dari kelompok sosial maupun lapisan sosial masyarakatnya. Kelompok sosial adalah kumpulan orang yang memiliki kesadaran bersama terhadap keanggotaanya dan saling berinteraksi, Robert Bierstedt.(1994:8)

Kondisi sosial yang ada dalam kehidupan masyarakat Sape Rasabou sangat beragam. Mereka memiliki ciri dan warna tersendiri yang membedakan dengan kondisi masyarakat di tempat lain. Kelompok social di Sape Rasabou tidak dapat di pahami dengan melihat perbedaan kualitas dan ciri angotanya saja. Tetapi Kelompok sosial dapat dipahami melalui struktur yang ada didalamnya sebagai suatu sistem yang utuh. Orang-orang yang berada dan menjadi anggota suatu kelompok di Sape Rasabou harus tunduk dan taat terhadap berbagai norma atau kaidah sosial yang berlaku. Dengan demikian, masingmasing anggota mencerminkan kepentingan kelompoknya. Jadi terbentuknya kondisi sosial di Sape Rsabou adalah tidak terlepas dari masyarakat Sape itu sendiri. artinya manusia tidak dapat hidup sendiri, ia memerlukan orang lain dalam masyarakat untuk memenuhi kebutuhan hidupnya. Hal itu terjadi karena secara biologis membutuhkan manusia yang lain untuk hidup bersama dalam memenuhi kebutuhan jasmani dan rohaninya.

Keadaan atau hasrat untuk hidup bersama yang dimiliki oleh Masyarakat Sape Rasabou, dari hasrat yang sama tersebut kemudian masyarakat Sape Rasabou membentukan kelompok. Selanjutnya setiap manusia berusaha untuk mengembangkan dirinya agar bisa diterima dan bermanfaat bagi orang lain untuk hidup bersama. Akhirnya itu menimbulkan kebudayaan kelompok yang disebut kelompok sosial (social group). Perasaan persatuan dalam kondisi sosial Sape Rasabou baru akan tercapai apabila setiap anggota kelompok mempunyai pandangan yang sama tentang masa depan bersama. Dengan demikian, dapat dikatakan bahwa kelompok sosial merupakan kesatuan manusia yang hidup bersama, memiliki hasrat yang sama, bekerja sama, memiliki perasaan yang sama, dan tujuan yang sama. Soerjono soekanto.(1990:3)

Lapisan sosial masyarakat Sape Rasabou biasanya terbagi atas masyarakat lapisan bawah, lapisan menengah, dan lapisan atas. Lapisan sosial masyarakat Sape Rasabou antara masyarakat kuno berbeda dengan masyarakat modern. 
Dari tingkatan masyarakatnya atau status sosial masyarakatnya. Tingkatan sosial atau status sosial bukan hanya saja tampak pada masa lalu hingga sekarang ini meskipun sudah mulai terjadi pergeseran akan tetapi nampaknya masih berlaku.

\section{b. Kehidupan Budaya Islam di Sape Rasabou.}

Kehidupan kebudayaan di Sape Rasabou Kabupaten Bima tampaknya antara Adat dan Kebudayaan Islam terdapat unsur-unsur yang sejalan atau islami. Hal tersebut merupakan konsekuensi logis dari adanya pengertian antara Adat dengan Kebudayaan Islam. Dapat dimengerti sebagai strategi dalam rangka proses lancarnya Islamisasi secara bijaksana tanpa adanya perasaan bagi masyarakat bahwa adanya islam merupakan ancaman bagi lembaga-lembaga adat. Namun demikian bukan berarti tidak ditemukan rintangan seperti dalam norma-norma yang dianutnya dimana terdapat pertentangan antara adat dengan syariat. Situasi demikian dituntut peran serta pemerintah sebagai sentral yang diharapkan mampu meratakan jalan untuk terwujudnya perdamaian dan kedamaian masyarakat.

Partisipasi Masyarakat dalam pengembangan Kebudayaan Islam tentu saja tidak terlepas dari kegiatan pembangunan, baik pembangunan mental maupun pembangunan fisik didalam mengembangkan kebudayaan islam. Kenyataannya bahwa dimana saja dan kapan saja dalam pembangunan mental selalu ada dakwah islam guna mendidik dan memelihara Akhlak serta perilaku yang jujur. Begitu juga mengenai pembangunan fisik, ditempat mana saja yang menjadi pemukiman masyarakat selalu dibangun tempat atau sarana ibadah, seperti Musholah, masjid, dan langgar.

Kesemuanya itu, merupakan partisipasi Masyarakat dalam pengembangan kebudayaan ditengahtengah masyarakat. Pelaksanaan pembangunan tersebut dilakukan secara gotong royong sebagai suatu prinsip bahwa kebersamaan dalam bentuk gotong royong sebagai hidup yang tidak lepas dari kekeluargaan.

Untuk mengembangkan kebudayaan islam di Sape Rasabou Kabupaten Bima, bukan hanya dengan pembangunan sarana peribadatan, tetapi juga dilakukan ceramah-ceramah atau pengajian-pengajian yang biasanya dilakukan secara bergiliran.
Tanpa kebudayaan manusia tidak akan hidup bersama dan bekerja sama untuk mempertahankan hidup dan eksistensinya, sebab itu masyarakat merupakan satu kesatuan sosial yang sangat erat kaitannya dengan budaya. Menurut (Gazalba 1983:44), bahwa “ diumpamakan kebudayaan itu otak, maka masyarakat merupakan tangan, otak berpikir tangan melaksanakan apa yang dipikirkan oleh otak".

Maka dengan demikian kebudayaan atau budaya dan masyarakat tidak mungkin dapat dipisahkan, karena soal kebudayaan adalah soal Manusia. Pembentukan dan pelaksanaan kebudayaan itu berpangkal pada hidup bersama dan bekerjasama sekelompok manusia. Demikian pula halnya agama dengan kebudayaan sulit untuk dipisahkan karena dengan pengalaman kebudayaan islam.

Kehidupan sosial masyarakat seperti diuraikan diatas, tidak terlepas dari nilai-nilai kebudayaan meskipun awalnya mereka membentuk masyarakat yang percaya kepada Animisme, Dinamisme dan Monoteisme, namun dengan masuknya islam, maka mereka mulai meninggalkan kepercayaan tersebut, seiring dengan mulainya terbentuk suatu budaya baru yaitu budaya islam. Kebudayaan islam terbentuk dengan adanya akulturasi dengan budaya setempat. Dengan berkembangnya islam di daerah tersebut, maka dengan sendirinya kebudayaan islam juga akan berkembang.

Masyarakat Islam di Sape Rasabou Kabupaten Bima, mulai membangun masyarakatnya dengan prinsipprinsip islami dan kebudayaan islam, sehingga dalam perkembangan Islam di Sape Rasabou Kabupaten Bima dapat dipahami secara mendasar oleh sebagian besar penduduknya sehingga ajaran islam berjalan dengan lancar.

3. Faktor-faktor pendukung dan penghambat dalam meningkatkan kehidupan Social Budaya Masyarakat Islam di Sape Rasabou Kabupaten Bima.

a. Faktor Penghambat dalam Meningkatkan Kehidupan Sosial Budaya

1) Hambatan material

Hambatan material merupakan hambatan yang paling dominan dalam perkembangan Islam di Sape Rasabou Kabupaten Bima, meskipun kedua masalah tersebut tidaklah terlalu melilit dalam mengembangkan ajaran islam, khususnya pendidikan agama islam, tetapi 
cukup dirasakan didaerah-daerah pelosok di Sape Rasabou, apalagi daerah tersebut dipenuhi dengan gunung-gunung, dengan tebing-tebing yang terjang disamping itu transportasi yang kurang memungkinkan.

2) Hambatan non material

Hambatan non material ini juga dirasakan oleh masyarakat di Sape Rasabou Kabupaten Bima, adapun hambatan yang dimaksud adalah:

a) Kurangnya tenaga Guru Agama Islam yang khusus membimbing para jamaah.

b) Tempat tinggal Masyarakat atau pemeluk agama islam yang saling berjauhan.

Masalah kehidupan yang dihadapi masyarakat islam, khususnya masyarakat terpencil di indonesia termasuk di Sape Rasabou Kabupaten Bima dapat dikatakan cukup banyak, peran serta kemampuan bersaing yang rendah, serta pengelolaan sumber-sumber ekonomi. Selain itu tingkat pengangguran yang tinggi, keterbatasan kemampuan dalam mengelolah bisnis, informasi dan teknologi.

Hal tersebut sejalan dengan pendapat Ado Sasono, (1998:59) bahwa, "ketidak merataan kemakmuran dan kesejahteran terjadi pada masyarakat islam di Sape Rasabou Kabupaten Bima yang terletak didaerah terpencil.

Dalam upaya menghadapi kesulitan-kesulitan didalam mengembangkan Ekonomi masyarakat islam di Sape Rasabou Kabupaten Bima diperlukan sumber daya manusia yang cukup, ini disebabkan karena daerah terpencil yang di Sape Rasabou, khususnya masyarakat islam didaerah terpencil sedapat mungkin dapat membawa perubahan pada faktor ekonomi, karena daerah terpencil di Sape Rasabou sangat berpotensi dengan sumber penghasilannya.

Salah satu upaya untuk meningkatkan kesejahteraan masyarakat islam di Sape Rasabou Kabupaten Bima adalah dengan mengembangkan potensi swadaya yang ada melalui kelompok-kelompok yang udah terbentuk dalam suatu Masyarakat.

Meskipun demikian, dengan melihat kondisi masyarakat islam di Sape Rasabou Kabupaten Bima sangatlah dituntut adanya kemampuan sumber daya manusia untuk memajukan perekonomian sehingga kehidupannya dapat lebih meningkat. Dimana masyarakat
Islam yang ada di daerah terpencil di Sape Rasabou Kabupaten Bima dapat mengali potensi daerahnya sehingga kehidupannya berlangsung dengan baik atau setidaknya mengalami peningkatan.

Untuk mencapai kehidupan yang lebih baik bagi masyarakat islam di Sape Rasabou Kabupaten Bima, maka pembangunan semua lapisan masyarakat haruslah mempunyai paling sedikit saran utama, sebagaimana dikemukakan oleh Prayitno, (1986:65-66) yaitu:

Meningkatkan persediaan dan memperluas

pembagian atau pemerataan bahan-bahan pokok yang dibutuhkan untuk dapat hidup seperti : makanan, tempat tinggal, kesehatan dan perlindungan.

Dalam upaya meningkatkan perekonomian Masyarakat Islam di Sape Rasabou Kabupaten Bima merupakan kewajiban semua pihak, dimana dapat dilihat dari perkembangan kehidupan Masyarakat terpencil yang huni oleh masyarakat islam, membutuhkan kehidupan yang lebih layak. Untuk mencapai tujuan tersebut, maka diupayakan untuk mencari jalan keluarnya didalam mengatasi kesulitan-kesulitan untuk pengembangan ekonomi masyarakat.

Adapun hambatan-hambatan yang dialami oleh masyarakat Islam di Sape Rasabou Kabupaten Bima adalah sebagai berikut :

\section{Transportasi dan Sarana Angkutan}

Transportasi dalam peranannya untuk meningkatkan perekonomian Masyarakat Islam di Sape Rasabou Kabupaten Bima, khususnya masyarakat islam yang terletak didaerah terpencil sangat dibutuhkan dengan alat transportasi tersebut, para petani dapat mengangkut sumber daya alam langsung menuju ke ibu kota kecamatan maupun ke ibu kota kabupaten bahkan keluar dari kabpaten Bima sehingga dapat meningkatkan penghasilan masyarakat, sebab dengan penghasilan yang meningkat dapat mensejahterakan masyarakat dengan sendirinya dapat menciptakan kehidupan yang lebih layak.

Sape Rasabou Kabupaten Bima terkenal dengan tanaman bawang merah, sayur-sayuran, dan sebagainya. Tetapi sulit untuk mengembangkan hasil perkebunan tersebut mengingat terbatasnya sumber daya manusia termasuk perlengkapan perkebunan, transportasi dan 
sarana angkutan sebagai contoh jenis sayur-sayuran biasanya untuk sayuran segar hanya bertahan 1-2 hari. Tetapi untuk sampai ke ibu kota kabupaten atau keluar dari kabupaten Bima membutuhkan waktu lebih dari itu sehingga kwalitasnya menurun yang dapat mempengaruhi harga masyarakat belum mampu mengelolah sumber daya alam tersebut menjadi barang yang langsung digunakan dengan cara pengawetan sehingga hasilnya langsung dijual ke pembeli dengan harga yang relative murah.

\section{Pendidikan yang rendah.}

Masalah pendidikan dan keterampilan yang dimiliki oleh masyarakat islam di Sape Rasabou Kabupaten Bima masih rendah karna itu membutuhkan tingkat pendidikan yang baik yang bersifat formal maupun yang bersifat non formal. Tingkat pendidikan masyarakat islam yang rendah menyebabkan daya kelola terhadap sumber daya alam kurang. Kurangnya daya kelola atau sumber daya manusia terhadap sumber daya alam. Masalah pendidikan masyarakat islam di Sape Rasabou Kabupaten Bima merupakan satu kendala didalam mengembangkan sumber daya alam.

b. Faktor pendukung untuk mengatasi hambatanhambatan dalam meningkatkan kehidupan social budaya Islam di Sape Rasabou

Hambatan-hambatan yang harus dihadapi oleh

para Tokoh Agama Islam dalam pengajaran islam di Sape Rasabou Kabupaten Bima, bukan berarti tidak ada upaya untuk mengatasinya dan inilah yang menjadi tantangan bagi para tokoh agama islam dan pemeluk islam dalam mengembangkan islam di daerah tersebut.

Untuk mengatasi hambatan-hambatan, maka dilakukan berbagai upaya, sebagai berikut :

a) Mengupayakan kerja sama yang baik dengan berbagai instansi, baik instansi pemerintah pemerintah maupun swasta, terutama dengan Depertemen Agama, Depertemen Pendidikan Nasional, dan Depertemen Peneragaan dan Depertemen lainnya, termasuk Tokohtokoh masyarakat. Dengan kerjasama tersebut diharapkan dapat saling membantu dalam meningkatkan bukan hanya sarana fisik akan tetapi pembinaan terhadap ajaran Islam, dengan harapan islam dapat berkembang dengan baik. Meskipun tidak dapat dipungkiri bahwa islam bukanlah satu-satunya yang perlu dikembangkan di Daerah tersebut. Akan tetapi dengan menggalang kerjasama tersebut diharapkan banyak memberikan bantuan dalam pengembangan masyarakat Islam sebagai masyarakat yang mayoritas di Sape Rasabou Kabupaten Bima.

b) Untuk mendapatkan dana dalam pengembangan islam di Sape Rasabou Kabupaten Bima selain dana dari Depertemen Agama untuk bantuan kecamatan, diadakan pula donatur dari para pengusaha islam, dermawan serta segenap umat islam untuk membantu pengembangan dana dari Departemen Agama untuk bantuan kecamatan, diadakan pula donatur dari pengusaha islam dan dermawan serta segenap umat islam untuk membantu pengembangan islam di Sape Rasabou Kabupaten Bima. Pengumpulan dana tersebut digunakan untuk membangun sarana fisik dan non fisik. Sarana fisik antara lain :

c) Sarana fisik seperti pengembangan sarana ibadah, masjid, musholah,sekolah-sekolah islamdan sebagainya.

d) Saran non fisik antara lain seperti pengajaran dan pendidikan kepada anak yatim piayatu,pengembangan santri, pemberdayaan masyarakat islam, kegiatan-kegiatan keagamaan dan sebagainya.

Dalam menuntaskan Masalah pendidikan dan pengajaran di Sape Rasabou kabupaten Bima, maka telah ditempuh upaya menyalurkan Guru-guru dalam sekolahsekolah formal. Sedangkan dari pendidikan non formal juga dilakukan pembinaan, misalnya guru-guru ngaji di rumah-rumah atau di Musholah-musholah merupakan upaya yang perlu mendapat bimbingan dan pengajaran sehingga dapat terlaksana dengan sebaik mungkin.

Untuk melestarikan dan pengembangan Islam di Sape Rasabou Kabupaten Bima, berbagai upaya pemerintah setempat dilakukan diantaranya : pendiri lembaga-lembaga pendidikan islam, diantara sekolahsekolah islam, pesantren dan sarana pendidikan islam lainnya.

Lembaga-lembaga pendidikan Islam tersebut diharapkan mampu untuk mengatasi hambatan-hambatan dalam pengajaran islam, sehingga dari waktu ke waktu nampak adanya perubahan yang mengarah pada 
pengembangan dan peningkatan mutu dalam berbagai dimensinya, sehingga apa yang didambakan oleh masyarakat islam di Sape Rasabou Kabupaten Bima dapat terpenuhi meskipun dilakukan secara bertahap dan berkesinambungan.

Selain mengembangkan Masyarakat Islam dalam berbagai aktifitas keislamannya, maka dibangun pula sarana- sarana ibadah bagi umat Islam di Sape Rasabou Kabupaten Bima.

Sehingga dapat disimpulkan bahwa adanya faktor penghambatan dalam pengajaran islam di Sape Rasabou Kabupaten Bima tersebut di atas, misalnya dalam pengembangan saranadan prasarana ibadah, lembagalembaga pendidikan baik sekolah agama maupun pesantren.

Hanya saja barang tentu masih mendapat hambatan terutama dalam bidang sosial ekonomi sehingga masyarakat yaitu masih rendahnya tingkat pendapatan masyarakat sehingga dalam pembangunan juga tertinggal, sebagai akibat belum mampunya mengelola secara maksimal sumber-sumber daya alam yang tersedia seperti perkebunan, pertanian, dan sebaginya.

Untuk mengatasi hambatan-hambatan dalam mengabangkan ajaran islam di Sape Rasabou Kabupaten Bima, maka masyarakat islam secara bersama-sama membangun masyarakat islam dan kebudayaan islam sehingga tercipta suatu Masyarakat yang menjalankan Islam sebagaimana mestinya tanpa mencapur adukan antara tradisi dengan ajaran Islam yang sesungguhnya.

\section{SIMPULAN DAN SARAN}

\section{Simpulan}

Berdasarkan Latar Belakang dan pembahasan Skripsi yang Berjudul "Kehidupan Sosial Budaya Masyarakat Islam di Desa Rasabou kecamatan Sape Kabupaten Bima 1931-1997”, maka Penulis dapat menarik kesimpulan sebagai berikut:

a) Masuknya Islam di Kabupaten Bima melalui kerajaan Gowa-Tallo pada tahun 1609 M. Kedatangan pedagang tersebut ke Bima, bukan hanya sematamata sebagai pedagang tetapi sambil menyebarkan agama islam. Daerah yang pertama kali didatangi oleh para pedagang islam ialah daerah bagian timur yaitu Daerah Sape, Daerah tersebut dapat menerima ajaran Islam dengan baik tanpa ada paksaan. Jadi, masuknya islam di kabupaten Bima tentunya membawa perubahan mendasar dalam kehidupan sosial budaya masyarakatnya, yang dulunya masih menganut kepercayaan beralih kepada agama islam. Kehidupan masyarakat tersebut terjadi baik dari aspek sosial maupun budaya.

b) Kondisi kehidupan sosial Budaya masyarakat islam di Desa Rasabou kecamatan Sape Kabupaten Bima berlangsung dalam kehidupan yang kegotongroyongan, meskipun terdapat perbedaan status sosial, namun mulai terjadi pergeseran semenjak masuknya ajaran islam bahwa manusia sama derajatnya kecuali yang membedakan adalah ketaqwaannya. Kehidupan budaya masyarakat islam Desa Rasabou kecamatan Sape berkembang sebagaimana berkembangnya agama islam diwilayah tersebut. Kebudayaan Islam terbentuk seiring dengan perkembangan agama Islam.

c) Faktor-faktor pendukung pengembangan agama Islam di Desa Rasabou kecamatan Sape Kabupaten Bima adalah sikap toleran masyarakat dengan masuknya ajaran islam. Ajaran islam didalam pengembangannya dilakukan secara damai tanpa ada paksaan, sarana dan prasarana ibadah sudah tersedia sehingga perlu memanfaatkan secara maksimal. Proses pemahaman ajaran islam dilakukan secara berangsur-angsur dengan mengunakan metode dan cara yang cukup jelas dan terarah. Sedangkan yang menjadi faktor penghambat pengembangan Islam di Desa Rasabou kecamatan Sape Kabupaten Bima adalah disebabkan oleh kurang tersedianya transportasi dan sarana jalan yang menghubungkan satu wilayah dengan wilayah lainnya sehingga dapat cepat berhubungan, khususnya dibidang Ekonomi juga disebabkan kurangnya tenaga pengajar atau pendidik, fasilitas yang perlu ditambah atau dibenahi, dan faktor dana. Olehnya itu perlu digalang kerjasama baik dengan Depertemen pendidikan Nasional, Depertemen Agama dan Depertemen-departemen lainnya, serta Tokoh-tokoh Masyarakat, Tokoh tokoh 
agama yang memberikan konstribusi dalam pengembangan Masyarakat Islam di Desa Rasabou kecamatan Sape Kabupaten Bima.

\section{Saran-Saran}

Berdasarkan hasil penelitian dan kesimpulan pada penelitian tentang Kehidupan Sosial Budaya Masyaraka Islam Desa Rasabou kecamatan Sape Kabupaten Bima 1931-1997. Maka Penulis menyampaikan saran-saran sebagai berikut :

a) Kepada pemerintah daerah Kabupaten Bima, khususnya kepada Depertemen Agama untuk lebih memperhatikan sejarah islam pada Masyarakat, khususnya pengembangan Agama Islam di Desa Rasabou kecamatan Sape, dengan cara memberikan bantuan baik berupa fasilitas, maupun penambahan tenaga pendidik atau Guru di Lembaga-lembaga pendidikan Islam dan juga sarana Transportasi diwilayah tersebut.

b) Masyarakat di Desa Rasabou kecamatan Sape Kabupaten Bima untuk secara bersama-sama menggalang kerjasama untuk memberikan dan membangun masyarakat dan Kebudayaan Islam Sehingga hambatan-hambatan yang dihadapi seperti rendahnya tingkat pendidikan dan ekonomi masyarakat akan segera terselesaikan.

c) Untuk penelitian selanjutnya, penulis sarankan mengkaji tentang prospek pengembangan Lembaga Kebudayaan Islam Desa Rasabou kecamatan Sape Kabupaten Bima.

\section{DAFTAR RUJUKAN}

Abdullah, Taufik, 1995. Ilmu Sejarah dan historiografi, arah dan prespektif, Gramedia, Jakarta.

Akbar H. Ishaka, S.Ag Hambatan atau Kondisi Daerah, Bima NT, Kantor Depertemen Agama

Bagong Suyanto, Metode Penelitian Sosial Berbagai Alternative Pendekatan Jakarta kencana 2011

Budiyono Sosiologi 2, Lapisan Social atau Stratifikasi Social Jakarta : pembukuan Depertemen Pendidikan Nasional 2009

Departemen Agama RI, 1994. Penyelenggaraan Pendidikan Formal di Pesanteren, Jakarta: proyek pembinaan dan bantuan pondok pesantren.
Dra. Hj. Mariam ((1971). Sejarah Masuk Islam di Bima, Bima Nusa Tenggara

H.Abdul Hamid (wawancara 05 Mei 2013), “ Potensi Pertanian Didaerah Sape Rasabou, Sape Bima NTB

Kitab BO (kitab sejarah bima, 1951:57), Peranan Kerajaan Gowa. Asi Mbojo Bima NTB

Koentjaraningrat. 1983. Manusia dan Kebudayaan di Indonesia

M.Fachrirrahman (2011) catatan kitab BO menujukan Islam Pertama Kali Masuk ke Bima, Bima NTB.

Muhtar Arsyad, 1998. Organisasi Muhammadiyah di Sape Rasabou, Sape Bima NTB

Notosusanto, Nugroho, 1971, Norma-norma Dasar Penelitian dan Penulisan Sejarah, Jakarta, Pusat Sejarah ABRI.

Poerwadarminta, W.J.S 1985. Kamus Umum Bahasa Indonesia, jakatra, Blai Pustaka.

Prayitno, Hadi, 1986. Ekonomi Pembangunan, Yogyakarta.

Rahmat, Jalaluddin 1986. Islam Alternatif, Bandung: Mizan.

Razak, Nasrudin, 1986. Dienul Islam, Bandung, Al-Muarif. 